\title{
CHEMOSPHERE
}

\section{Inhibition of PCDD/Fs formation from dioxin precursors by calcium oxide}

\author{
Wenbin Liu, Minghui Zheng *, Bing Zhang, Yong Qian, \\ Xiaodong Ma, Wenxia Liu \\ State Key laboratory of Environmental Chemistry and Ecotoxicology, Research Center for Eco-Environmental Sciences, \\ Chinese Academy of Sciences, P.O. Box 2871, Beijing 100085, PR China
}

Available online 8 June 2005

\begin{abstract}
Research aimed at understanding the inhibition effect of $\mathrm{CaO}$ on polychlorinated dibenzo-p-dioxins and dibenzofurans $(\mathrm{PCDD} / \mathrm{Fs})$ formation form dioxins precursors, such as chlorophenols $(\mathrm{CPs})$ and chlorobenzenes $(\mathrm{CBs})$. The results indicated that a clear dioxin inhibition effect occurred both in open and sealed system when $\mathrm{CaO}$ was used. In the open system, PCDDs were the main congeners and the inhibition efficiency was all over $99 \%$ in the experiments. In the experiments with $\mathrm{CaO}$, less than $0.1 \%$ of the initial PCP was detected in the absorption tube and only about $1 \%$ of the initial PCP was examined as calcium pentachlorophenate in the reaction tube. In the sealed system, the inhibition efficiency was over $90 \%$ at temperature range between 280 and $450{ }^{\circ} \mathrm{C}$ when PCP was used as model precursor. When $\mathrm{HCB}$ and 2,3,4,5- $\mathrm{T}_{4} \mathrm{CP}$ replaced PCP, significant inhibition effect was also observed. As $\mathrm{CaO}$ has the advantageous properties of non-toxicity and non-volatile nature, it is our hope that the result will contribute to the development of a new technique to cope with the problem of dioxin pollution in MWIs.
\end{abstract}

(c) 2005 Elsevier Ltd. All rights reserved.

Keywords: PCDD/Fs; Dioxin precursor; CaO; Inhibition; Incinerator

\section{Introduction}

The presence of polychlorinated dibenzo-p-dioxins and dibenzofurans $(\mathrm{PCDD} / \mathrm{Fs})$ in the effluents of incinerators was widely recognized as a major source of dioxins in the environment. PCDD/Fs were always detected in stack gas and fly ash from municipal waste incinerators (MWIs) (Olie et al., 1977). As a result of many investigations, the theories of precursor formation and

\footnotetext{
* Corresponding author. Tel.: +86106284 9172; fax: +8610 62923563.

E-mail address: zhengmh@mail.rcees.ac.cn (M. Zheng).
}

de novo formation have been developed to describe the pathways and mechanisms of PCDD/Fs formation in stack gas of incinerators.

The decisive role of chlorophenols (CPs) and chlorobenzenes (CBs) could hardly be challenged in $\mathrm{PCDD} / \mathrm{Fs}$ formation (Altwicker, 1996; Milligan and Altwicker, 1996; Weber and Hagenmaier, 1999; Iino et al., 2000; Catherine and Dellinger, 2003). These classes of compounds were always found together with $\mathrm{PCDD} / \mathrm{Fs}$ in the effluents of incinerators and have been suggested as indicator compounds. Concentrations of CBs and CPs could be correlated with that of PCDD/Fs in stack gas of incinerators (Kaune et al., 1998; Lenoir et al., 2001). CBs concentrations were typically about three orders of 
magnitude greater than PCDD/Fs in incinerator effluents and CPs concentrations were a factor of 5 larger than PCDD/Fs, although yields varied from incinerator to incinerator. In addition, PCDDs formation was strongly related to CPs concentration (Tuppurainen et al., 2000; Stanmore, 2002). Dickson et al. (1992) found that PCDD/Fs formation from model precursor compound pentachlorophenol (PCP) was 72-99000 times greater than that from carbon via de novo mechanism. Altwicker concluded from his kinetic calculations that PCDD/Fs were formed much faster from precursors than from carbon in fly ash and that chlorophenols therefore represented key molecules in PCDD/Fs formation in combustion processes (Weber and Hagenmaier, 1999).

A large number of dioxin emission control techniques in MWIs were concerned mainly with the "end of pipe" or secondary measures such as wet/dry scrubbing, fabric filtration, active carbon adsorption and so on. These approaches were focused on the project by means of gas cleaning devices, increasing the installation and operation costs. The best way, however, is to block PCDD/ Fs formation in stack gas and mitigate the dioxins pollution in MWIs.

Various chemical inhibitors have been tested to reduce PCDD/Fs formation both in the laboratories and pilot plants. Several alkali chemicals were reported to suppress the formation of PCDD/Fs (Karasek et al., 1992). Different studies revealed the inhibition ability of some basic compounds such as $\mathrm{NH}_{3}$ (Ruokojärvi et al., 1998), $\mathrm{CaO}$ (Naikwadi and Karasek, 1989), $\mathrm{NaOH}$ and $\mathrm{KOH}$ (Naikwadi et al., 1993). The presence of compounds containing sulfur and nitrogen affected PCDD/Fs formation pathways, as it was observed from the ratios and the homologue profiles of PCDDs and PCDFs (Xhrouet et al., 2002; Samaras et al., 2000; Raghunathan and Gullett, 1996). Tuppurainen et al. (1999) studied the effect of two liquid inhibitors, sodium ammonium hydrogen phosphate and urea, on PCDD/Fs formation in the combustion of liquid fuel doped with copper and chlorine at a pilot-scale plant. It should be emphasized that the use of inhibitors has been limited so far to the laboratory only and few were on the practice application.

Calcium oxide has been used mainly as a good absorber of $\mathrm{HCl}$ and $\mathrm{SO}_{2}$ in the low temperature zone of an incinerator for a long time, where the temperature of the flue gas scrubber system was commonly below $250{ }^{\circ} \mathrm{C}$. Though Naikwadi and Karasek (1989) reported PCDD/Fs formation by catalysis of fly ash from PCP at $300{ }^{\circ} \mathrm{C}$ can be reduced by $\mathrm{CaO}$, there is no further research to disclose the influence of $\mathrm{CaO}$ on dioxin formation from dioxin precursors. In this paper, pentachlorophenol (PCP), hexachlorobenzene (HCB) and 2,3,4,5-tetrachlorophenol $\left(2,3,4,5-\mathrm{T}_{4} \mathrm{CP}\right)$ were selected as model dioxin precursors to investigate the inhibition effect of $\mathrm{CaO}$. As $\mathrm{CaO}$ has the advantageous properties of non-toxicity and non-volatile nature, it is our hope that the result will contribute to the development of a new technique to cope with the problem of dioxin pollution in MWIs.

\section{Experimental section}

A schematic of experimental apparatus used in this study is shown in Fig. 1. Simulate experiments were carried out in it to estimate inhibition effect of $\mathrm{CaO}$. The length and inner diameter of quartz glass reaction tube were 250 and $10 \mathrm{~mm}$, respectively. Quartz grain with diameter $1 \mathrm{~mm}$ was used as additive. Two absorption tubes with $80 \mathrm{ml}$ toluene were placed into ice water. Before being passed through the reaction tube, $5 \mathrm{mg}$ PCP was pre-heated in the pre-heater at $250{ }^{\circ} \mathrm{C}$ and evaporated into the reaction tube slowly under the air flow of $10 \mathrm{ml} / \mathrm{min}$. The oven temperature was set at $350{ }^{\circ} \mathrm{C}$ and the reaction time lasted $2 \mathrm{~h} .0 .8 \mathrm{~g} \mathrm{CaO}$ and $15.2 \mathrm{~g}$ quartz grain were mixed manually and placed into the reaction tube in the experiment of $5 \% \mathrm{CaO}$, while $3.2 \mathrm{~g}$ $\mathrm{CaO}$ and $12.8 \mathrm{~g}$ quartz grain in the experiment of $20 \%$ $\mathrm{CaO}$. Other experiments were carried out in sealed glass tube with diameter $8 \mathrm{~mm}$ and length $100 \mathrm{~mm}$.

The samples were extracted with $5 \%$ toluene/n-hexane by ultrasonic extraction and cleaned with alkali $\mathrm{Al}_{2} \mathrm{O}_{3}$ column. PCDD/Fs analysis was carried out by isotope dilution method with Agilent $6890 \mathrm{GC} / 5973 \mathrm{~N}$ MS using a 30-m DB-5 fused-silica column. The quantification analysis of PCDD/Fs was performed in selected ion monitoring (SIM) mode. 2,3,7,8-Cl-substituted PCDD/Fs and total PCDD/Fs were analyzed. No analyses of the species without chlorine or less than four chlorines were performed. Polychlorophenols were also analyzed to investigate the PCDD/Fs formation. Polychlorophenols were derivatized with pentafluorobenzoyl chloride as a derivatizing reagent and analyzed by GC/ ECD (Bao and Dong, 1990).

\section{Results and discussion}

Calcium oxide was tested to study its effect towards the prevention of $\mathrm{PCDD} / \mathrm{Fs}$ formation. The inhibition

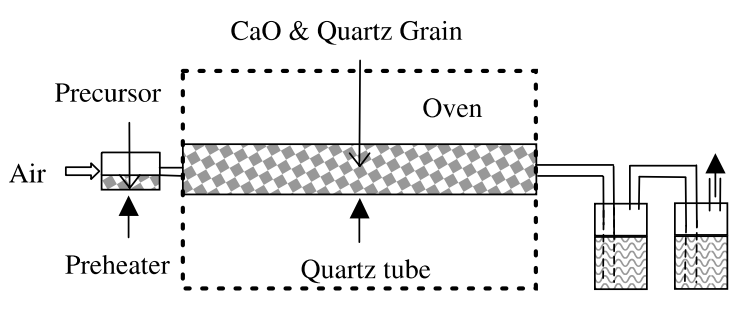

Fig. 1. Schematic of the experimental apparatus. 
tests were compared to reference experiments, which consist of thermal experiments performed without $\mathrm{CaO}$. Inhibition efficiency of $\mathrm{CaO}$ was calculated from the reference tests. Some experiments were carried out in the experimental apparatus, while others were done in the sealed glass tube. The results indicated that a clear dioxin inhibition effect occurred both in open and sealed systems when $\mathrm{CaO}$ was used.

The analytical results of dioxins obtained from the experimental apparatus are shown in Fig. 2. In this open system, PCDDs were the main congeners and the inhibition efficiency was all over $99 \%$ in the experiments. $\mathrm{T}_{4} \mathrm{CDD}$ to OCDD, $\mathrm{T}_{4} \mathrm{CDF}$ and OCDF were detected in the reference experiment in which only quartz grain was used as the additive, while OCDD and $\mathrm{T}_{4} \mathrm{CDF}$ were detected in the experiment of $5 \% \mathrm{CaO}$ and only OCDD were detected in the experiment of $20 \% \mathrm{CaO}$. The conversion from CPs to PCDDs at about $300^{\circ} \mathrm{C}$ has been verified experimentally and the most abundant PCDD congeners have been obtained in the previous works (Born et al., 1993; Tuppurainen et al., 1998). These condensation reactions are postulated to take place via Smiles rearrangement with a dioxaspiro-type compound as an intermediate.

Remainder PCP in the pre-heater, reaction tube and absorption tube was also analyzed. The reaction time was determined by the amount of the remainder PCP in the pre-heater, and it lasted $2 \mathrm{~h}$ until the remainder PCP was less than $0.1 \%$ of the initial PCP. In the reference test, $75.4 \%$ of the initial PCP was detected in the absorption tube and less than $0.5 \%$ of the initial PCP was detected in the reaction tube. As a contrast, in the experiments with $\mathrm{CaO}$, less than $0.1 \%$ of the initial PCP was detected in the absorption tube and only about $1 \%$ of the initial PCP was examined as calcium pentachlorophenate in the reaction tube, which means that PCP was absorbed by $\mathrm{CaO}$ and decomposed in the reac- tion tube. The inhibition effects obtained from some experiments as a function of the reaction times in the sealed glass tubes are listed in Fig. 3. PCP was used as the model precursor and mixed manually with 20 times of $\mathrm{CaO}$. $\mathrm{CaO}$ suppressed the dioxins formation so that

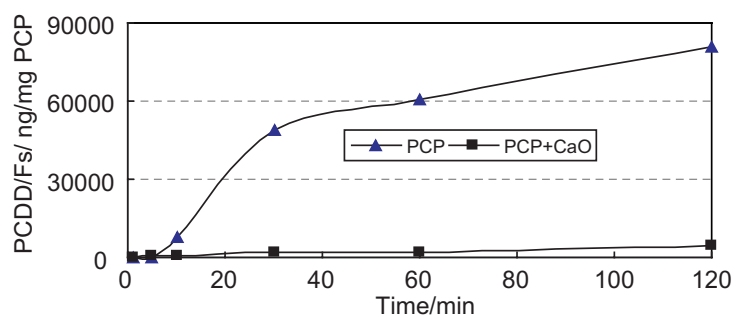

Fig. 3. Inhibition effect of $\mathrm{CaO}$ on the dioxins formation from $\mathrm{PCP}$ at different reaction times $(1 \mathrm{mg}$ PCP, $20 \mathrm{mg} \mathrm{CaO}$, reaction temperature $280^{\circ} \mathrm{C}$ ).

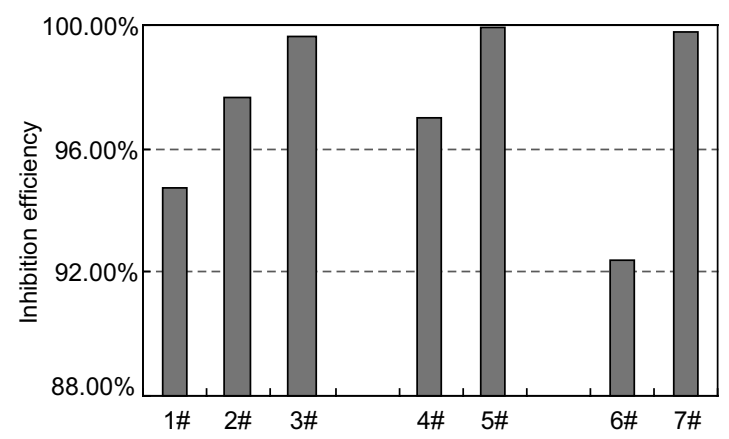

Fig. 4. Inhibition efficiency of $\mathrm{CaO}$ at different temperatures $\left(1 \mathrm{mg}\right.$ PCP, reaction time $2 \mathrm{~h}, 1 \#: 280^{\circ} \mathrm{C}, 20 \mathrm{mg} \mathrm{CaO} ; 2 \#$ : $280^{\circ} \mathrm{C}, 50 \mathrm{mg} \mathrm{CaO} ; 3 \#: 280{ }^{\circ} \mathrm{C}, 100 \mathrm{mg} \mathrm{CaO} ; 4 \#: 350^{\circ} \mathrm{C}$, $20 \mathrm{mg} \mathrm{CaO} ; 5 \#: 350^{\circ} \mathrm{C}, 150 \mathrm{mg} \mathrm{CaO} ; 6 \#: 450^{\circ} \mathrm{C}, 20 \mathrm{mg} \mathrm{CaO}$; 7\#: $\left.450{ }^{\circ} \mathrm{C}, 150 \mathrm{mg} \mathrm{CaO}\right)$.

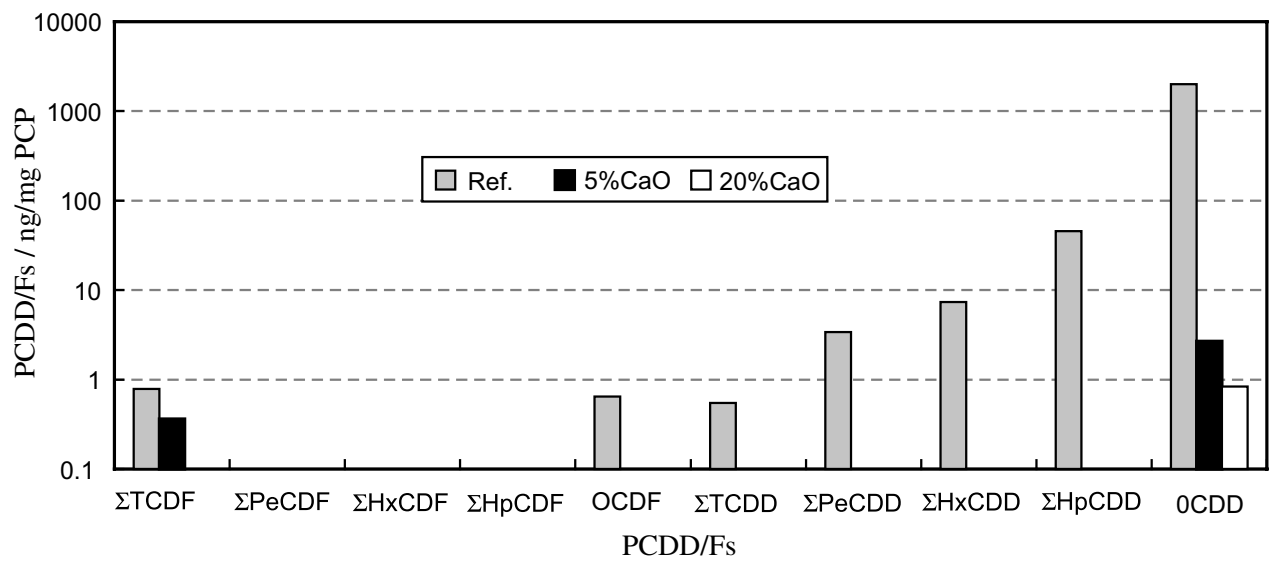

Fig. 2. Inhibition effect of $\mathrm{CaO}$ on dioxins formation from $\mathrm{PCP}$ in the experimental apparatus (reaction temperature $350{ }^{\circ} \mathrm{C}$, reaction time $2 \mathrm{~h}$, air flow $10 \mathrm{ml} / \mathrm{min}, 5 \mathrm{mg} \mathrm{PCP}, 0.8 \mathrm{~g} \mathrm{CaO}$ and 15.2 quartz grain in 5\% CaO; $3.2 \mathrm{~g} \mathrm{CaO}$ and 12.8 quartz grain in $20 \% \mathrm{CaO}$ ). 
the concentrations of dioxins could be maintained in a relatively low level.

A comparison of the inhibition efficiency obtained at the different reaction temperature and the ratio of $\mathrm{CaO}$ to PCP is presented in Fig. 4. In the sealed glass tubes, the reaction lasted $2 \mathrm{~h}$ in order that chemical reaction equilibrium could be achieved. It can be observed that the inhibition efficiency increased when more amount of $\mathrm{CaO}$ was added. The inhibition efficiency was over $90 \%$ at temperature range between 280 and $450{ }^{\circ} \mathrm{C}$. Increasing the amount of $\mathrm{CaO}$ to 150 times of PCP, the inhibition efficiency could reach $99 \%$.

The homologue profiles and inhibition yields at target temperatures in the sealed glass tubes are given in

Table 1

The homologue profiles of PCDD/Fs at various temperatures (ng/mg PCP)

\begin{tabular}{|c|c|c|c|c|c|c|c|c|}
\hline Congeners & $8 \#$ & $9 \#$ & $10 \#$ & $11 \#$ & $12 \#$ & $13 \#$ & $14 \#$ & $15 \#$ \\
\hline $1,2,3,4,7,8-\mathrm{H}_{6} \mathrm{CDD}$ & 1.6 & ND & ND & ND & ND & ND & ND & ND \\
\hline $1,2,3,6,7,8-\mathrm{H}_{6} \mathrm{CDD}$ & 2.7 & ND & ND & ND & 3.6 & 3.1 & ND & 6.6 \\
\hline $1,2,3,7,8,9-\mathrm{H}_{6} \mathrm{CDD}$ & 8.2 & ND & ND & ND & 6.0 & 5.5 & ND & ND \\
\hline$\sum \mathrm{H}_{6} \mathrm{CDDs}$ & 33 & ND & ND & ND & 50 & 19 & ND & 6.6 \\
\hline $1,2,3,4,6,7,8-\mathrm{H}_{7} \mathrm{CDD}$ & 320 & 8.9 & 181 & 191 & 280 & 25 & 64 & 60 \\
\hline$\sum \mathrm{H}_{7} \mathrm{CDDs}$ & 750 & 16 & 595 & 234 & 600 & 100 & 134 & 92 \\
\hline $\overrightarrow{\mathrm{OCDD}}$ & 80040 & 4243 & 91330 & 897 & 104400 & 3050 & 22500 & 1610 \\
\hline$\sum \mathrm{PCDDs}$ & 80823 & 4259 & 91925 & 1131 & 105050 & 3169 & 22634 & 1709 \\
\hline$\sum \mathrm{PCDFs}$ & ND & ND & ND & ND & ND & ND & ND & ND \\
\hline Inhibition efficiency of total PCDD/Fs & \multicolumn{2}{|c|}{$94.7 \%$} & \multicolumn{2}{|c|}{$98.8 \%$} & \multicolumn{2}{|c|}{$97.0 \%$} & \multicolumn{2}{|c|}{$92.4 \%$} \\
\hline
\end{tabular}

$1 \mathrm{mg} \mathrm{PCP}$, reaction time $2 \mathrm{~h}, 8 \#: 280^{\circ} \mathrm{C}$, without $\mathrm{CaO} ; 9 \#: 280^{\circ} \mathrm{C}, 20 \mathrm{mg} \mathrm{CaO} ; 10 \#: 300{ }^{\circ} \mathrm{C}$, without $\mathrm{CaO} ; 11 \#: 300{ }^{\circ} \mathrm{C}, 20 \mathrm{mg} \mathrm{CaO}$; 12\#: $350{ }^{\circ} \mathrm{C}$, without $\mathrm{CaO} ; 13 \#: 350{ }^{\circ} \mathrm{C}, 20 \mathrm{mg} \mathrm{CaO} ; 14 \#: 450{ }^{\circ} \mathrm{C}$, without $\mathrm{CaO} ; 15 \#: 450{ }^{\circ} \mathrm{C}, 20 \mathrm{mg} \mathrm{CaO}$.

Table 2

The homologue profiles of PCDD/Fs with various precursors (ng/mg precursor)

\begin{tabular}{|c|c|c|c|c|c|c|}
\hline Congeners & $16 \#$ & $17 \#$ & $18 \#$ & $19 \#$ & $20 \#$ & $21 \#$ \\
\hline$\overline{\sum \mathrm{TCDD}}$ & ND & ND & ND & ND & 1.7 & ND \\
\hline$\sum \mathrm{TCDF}$ & ND & ND & ND & 0.022 & ND & ND \\
\hline$\sum \mathrm{P}_{5} \mathrm{CDF}$ & ND & ND & ND & ND & ND & ND \\
\hline $1,2,3,7,8-\mathrm{P}_{5} \mathrm{CDD}$ & ND & ND & ND & ND & 1.6 & 1.0 \\
\hline$\sum \mathrm{P}_{5} \mathrm{CDD}$ & ND & ND & ND & ND & 11.8 & 6.6 \\
\hline $1,2,3,6,7,8-\mathrm{H}_{6} \mathrm{CDF}$ & ND & ND & ND & ND & 0.57 & 0.64 \\
\hline $1,2,3,7,8,9-\mathrm{H}_{6} \mathrm{CDF}$ & ND & ND & ND & ND & 2.1 & 1.29 \\
\hline$\sum \mathrm{H}_{6} \mathrm{CDF}$ & ND & ND & ND & ND & 51.9 & 27.3 \\
\hline $1,2,3,4,7,8-\mathrm{H}_{6} \mathrm{CDD}$ & ND & ND & ND & 0.0091 & ND & ND \\
\hline $1,2,3,6,7,8-\mathrm{H}_{6} \mathrm{CDD}$ & ND & ND & ND & 0.010 & 1235 & 133 \\
\hline $1,2,3,7,8,9-\mathrm{H}_{6} \mathrm{CDD}$ & ND & ND & ND & 0.0068 & 765 & 73 \\
\hline$\sum \mathrm{H}_{6} \mathrm{CDD}$ & ND & ND & ND & 0.059 & 6862 & 918 \\
\hline $1,2,3,4,6,7,8-\mathrm{H}_{7} \mathrm{CDF}$ & ND & ND & ND & 0.056 & 41 & 19 \\
\hline $1,2,3,4,7,8,9-\mathrm{H}_{7} \mathrm{CDF}$ & ND & ND & ND & ND & 2.9 & ND \\
\hline$\sum \mathrm{H}_{7} \mathrm{CDF}$ & ND & ND & ND & 0.066 & 130 & 63 \\
\hline $1,2,3,4,6,7,8-\mathrm{H}_{7} \mathrm{CDD}$ & 23 & 1.5 & 0.082 & 0.021 & 1135 & 200 \\
\hline$\sum \mathrm{H}_{7} \mathrm{CDD}$ & 43 & 2.0 & 0.13 & 0.024 & 2036 & 382 \\
\hline OCDD & 20600 & 120 & 10.0 & 1.08 & 128 & 34 \\
\hline OCDF & 23 & 0.48 & 11.0 & 0.71 & 37 & 18 \\
\hline$\sum \mathrm{TCDD}$ to OCDD & 20643 & 122 & 10.3 & 1.4 & 9039 & 1340 \\
\hline$\sum \mathrm{TCDF}$ to $\mathrm{OCDF}$ & 23 & 0.48 & 11.0 & 0.79 & 220 & 109 \\
\hline$\sum \mathrm{PCDD} / \mathrm{Fs}$ & 20666 & 122 & 21.3 & 2.2 & 9058 & 1449 \\
\hline I-TEQ & 21 & 0.14 & 0.022 & 0.0052 & 213 & 24 \\
\hline Inhibition efficiency of total PCDD/Fs & \multicolumn{2}{|c|}{$99.4 \%$} & \multicolumn{2}{|c|}{$89.8 \%$} & \multicolumn{2}{|c|}{$84.3 \%$} \\
\hline Inhibition efficiency of I-TEQ & \multicolumn{2}{|c|}{$99.4 \%$} & \multicolumn{2}{|c|}{$76.4 \%$} & \multicolumn{2}{|c|}{$89.0 \%$} \\
\hline
\end{tabular}

Reaction time $5 \mathrm{~min}$, reaction temperature $350^{\circ} \mathrm{C}, 16 \#: 1 \mathrm{mg} \mathrm{PCP}$, without $\mathrm{CaO} ; 17 \#: 1 \mathrm{mg} \mathrm{PCP}, 20 \mathrm{mg} \mathrm{CaO} ; 18 \#: 1 \mathrm{mg} \mathrm{HCB}$,

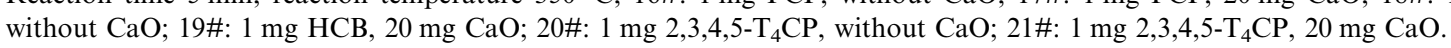


Table 1. These tests of PCP with 20 times $\mathrm{CaO}$ were carried out at temperature range between 280 and $450^{\circ} \mathrm{C}$ and the reaction lasted $2 \mathrm{~h}$. It can be seen from Table 1 , the maximum of dioxins formation from PCP without $\mathrm{CaO}$ was achieved at $350{ }^{\circ} \mathrm{C}$. The best inhibition efficiency was $98.8 \%$ at $300{ }^{\circ} \mathrm{C}$ and all others exceeded $90 \%$ at other temperatures. OCDD were formed preferentially and the amount of all other congeners was as little as $2 \%$ of OCDD.

Further experiments were designed to study the inhibition effect of $\mathrm{CaO}$ when PCP was replaced by other dioxin precursor, such as $\mathrm{HCB}$ and $2,3,4,5-\mathrm{T}_{4} \mathrm{CP}$, in the sealed glass tubes. The results are given in Table 2 . Although the reaction time only lasted $5 \mathrm{~min}$ at $350{ }^{\circ} \mathrm{C}$, the significant inhibition effect was also found. This result was different from the reaction at $280^{\circ} \mathrm{C}$, which no inhibition effect was observed when reaction time was $5 \mathrm{~min}$. The probable reason was that the reaction rate in $350{ }^{\circ} \mathrm{C}$ is far faster than in $280^{\circ} \mathrm{C}$. The best inhibition efficiency of total PCDD/Fs achieved at $99.4 \%$ in the experiment of PCP with $\mathrm{CaO}$, while the lowest inhibition efficiency was $84.3 \%$ when the precursor was $2,3,4,5-\mathrm{T}_{4} \mathrm{CP}$. It was also observed that the amount of $\mathrm{PCDD} / \mathrm{Fs}$ synthesized from PCP was more than that from 2,3,4,5- $\mathrm{T}_{4} \mathrm{CP}$ and $\mathrm{HCB}$. The amount of $\mathrm{PCDD} /$ Fs resulting from 2,3,4,5- $\mathrm{T}_{4} \mathrm{CP}$ and $\mathrm{HCB}$ was $43.8 \%$ and $0.1 \%$ of which from PCP in the reference experiments, respectively.

When the flue gas leaves the primary combustion chamber, some organic materials, particularly the dioxin precursors, cool down from high temperature and subsequently condense, and it is during this molecular rearrangement that $\mathrm{PCDD} / \mathrm{Fs}$ are formed, commonly in the temperature range between 650 and $250^{\circ} \mathrm{C}$ (Tuppurainen et al., 1998). According to this study, $\mathrm{CaO}$ may be applied in the post-combustion zone of MWIs in the temperature range between 650 and $250^{\circ} \mathrm{C} . \mathrm{CaO}$ powder could be sprayed into the post-combustion zone of incinerator at $650^{\circ} \mathrm{C}$, and then the cooling process of flue gas occurs in the presence of $\mathrm{CaO}$. The dioxin precursors are absorbed and decomposed by $\mathrm{CaO}$ and thus. the PCDD/Fs formation from dioxin precursors is inhibited by $\mathrm{CaO}$, In addition, $\mathrm{CaO}$ could also absorb $\mathrm{HCl}$ and prevent the formation of $\mathrm{Cl}_{2}$ from $\mathrm{HCl}$. In a word, $\mathrm{CaO}$ serves multiple goals, such as reducing $\mathrm{PCDD} / \mathrm{F}$ formation, attacking precursors and also reducing $\mathrm{HCl}$, that would provide an effective method of control of PCDD/Fs and acidic gases in MWIs.

\section{Acknowledgments}

This study was supported by National Basic Research Program of China (Grant No. 2003CB415006) and National Natural Science Foundation of China (Grant Nos. 20177031, 20122202).

\section{References}

Altwicker, E.R., 1996. Relative rates of formation of polychlorinated dioxins and furans from precursor and de novo reactions. Chemosphere 33, 1897-1904.

Bao, Z., Dong, J., 1990. Gas chromatographic determination of phenols in water by capillary GC/ECD. Chin. Environ. Chem. 9, 26-33.

Born, J.G.P., Mulder, P., Louw, R., 1993. Fly ash mediated reactions of phenol and monochlorophenols: oxychlorination, deep oxidation, and condensation. Environ. Sci. Technol. 27, 1849-1863.

Catherine, S.E., Dellinger, B., 2003. Mechanisms of dioxin formation from the high-temperature pyrolysis of 2-chlorophenol. Environ. Sci. Technol. 37, 1325-1330.

Dickson, L.C., Lenoir, D., Hutzinger, O., 1992. Quantitative comparison of de novo and precursor formation of polychlorinated dibenzo-p-dioxins under simulated municipal solid waste incinerator postcombustion conditions. Environ. Sci. Technol. 26, 1822-1828.

Iino, F., Imagama, T., Gullett, B.K., 2000. Dechlorinationcontrolled polychlorinated dibenzofuran isomer patterns from municipal waste incinerators. Environ. Sci. Technol. 34, 3143-3147.

Karasek, F.W., Naikwadi, K., Hutzinger, O., 1992. US Patent 5113772.

Kaune, A., Lenoir, D., Schramm, K.W., Zimmermann, R., Kettrup, A., Jaeger, K., Rückel, H.G., Frank, F., 1998. Chlorobenzenes and chlorophenols as indicator parameters for chlorinated dibenzodioxins and dibenzofurans in incineration processes: influences of various facilities and sampling points. Environ. Eng. Sci. 15, 85-96.

Lenoir, D., Wehrmeier, A., Sidhu, S.S., Taylor, P.H., 2001. Formation and inhibition of chloroaromatic micropollutants formed in incineration processes. Chemosphere 43, 107-114.

Milligan, M.S., Altwicker, E.R., 1996. Chlorophenol reactions on fly ash. 1. Adsorption/desorption equilibria and conversion to polychlorinated dibenzo-p-dioxins. Environ. Sci. Technol. 30, 225-229.

Naikwadi, K.P., Albrecht, I.D., Karasek, F.W., 1993. Mechanism of formation of PCDD/PCDF in industrial waste incineration and a method of prevention of their formation. Chemosphere 27, 335-342.

Naikwadi, K.P., Karasek, F.W., 1989. Prevention of PCDD formation in MSW incinerators by inhibition of catalytic activity of fly ash produced. Chemosphere 19, 299-304.

Olie, K., Vermeulen, P.L., Hutzinger, O., 1977. Chlorodibenzo$p$-dioxins and chlorodibenzofurans are trace components of fly ash and flue gas of some municipal incinerators in The Netherlands. Chemosphere 6, 455-459.

Raghunathan, K., Gullett, B.K., 1996. Role of sulfur in reducing PCDD and PCDF formation. Environ. Sci. Technol. 30, 1827-1834.

Ruokojärvi, P.H., Halonen, I.A., Tuppurainen, K.A., Tarhanen, J., Ruuskanen, J., 1998. Effect of gaseous inhibitors on PCDD/F formation. Environ. Sci. Technol. 32, 3099-3103.

Samaras, P., Blumenstock, M., Lenoir, D., Schramm, K.W., Kettrup, A., 2000. PCDD/F prevention by novel inhibitors: addition of inorganic S- and N-compounds in the fuel before combustion. Environ. Sci. Technol. 34, 5092-5096. 
Stanmore, B.R., 2002. Modeling the formation of PCDD/F in solid waste incinerators. Chemosphere 47, 565-573.

Tuppurainen, K., Aatamila, M., Ruokojärvi, P., Halonen, I., Ruuskanen, J., 1999. Effect of liquid inhibitors on PCDD/F formation. Prediction of particle-phase PCDD/F concentrations using PLS modelling with gas-phase chlorophenol concentrations as independent variables. Chemosphere 38, 2205-2217.

Tuppurainen, K.A., Halonen, I., Ruokojärvi, P., Tarhanen, J., Ruuskanen, J., 1998. Formation of PCDDs and PCDFs in municipal waste incineration and its inhibition mechanisms: a review. Chemosphere 36, 1493-1511.
Tuppurainen, K.A., Ruokojarvi, P.H., Asikainen, A.H., Aatamila, M., Ruuskanen, J., 2000. Chlorophenols as precursors of PCDD/FS in incineration processes: correlations, PLS modeling, and reaction mechanisms. Environ. Sci. Technol. 34, 4958-4962.

Weber, R., Hagenmaier, H., 1999. Mechanism of the formation of polychlorinated dibenzo-p-dioxins and dibenzofurans from chlorophenols in gas phase reactions. Chemosphere 38, 529-549.

Xhrouet, C., Nadin, C., Pauw, E.D., 2002. Amines compounds as inhibitors of $\mathrm{PCDD} / \mathrm{Fs}$ de novo formation on sintering process fly ash. Environ. Sci. Technol. 36, 2760-2765. 